\author{
Sławomir Kwiecień \\ dr inż. \\ Politechnika Śląska, \\ Wydział Budownictwa \\ slawomir.kwiecien@polsl.pl
}

\title{
The influence of loading plate diameter on the results of trial load tests of dynamic replacement columns
}

\begin{abstract}
The dynamic replacement method of soil strengthening consists in the constructing columns made of aggregate of various granularity. In order to form them, heavy pounders (weighing from 10 to 20 tonnes) are dropped from the height of $25 \mathrm{~m}$. Considering the specificity of this technique, it is quite important to verify on site the assumptions of the project, such as diameter and length of columns, their compaction or stiffness. For that reason, a number of examinations are performed, including column excavations, various types of probing tests or trial loads. The latter consists in determining the "load-settlement" dependence - usually during initial and secondary loadings phase - and on their basis, indicating the value of deformation modulus. Therefore, a stiff plate is placed on the column head and the loading is realised using actuators leaning on the ballast. The diameter of the loading plate depends on diameter and length of column and on the predicted pressure under the plate. The diameter of the loading plate is often smaller than column's diameter. This paper tries to determine the influence of the diameter of the plate used in test loads on the result of the research presented as "load-settlement" dependence and on the values of deformation modulus determined on their basis. The calculations were performed using FEM on a spatial numerical model calibrated on the basis of column's bearing capacity tests. Two models were applied in calculations: elastic-ideally plastic and isotropic hardening elastoplastic.
\end{abstract}

Keywords: Dynamic replacement; Load plate test; Numerical analysis

\section{Introduction}

Over the past several years the dynamic exchange method has been used to strengthen the subsoil of many road routes (A1, A2, A4, S7, ring roads of many cities). This fast and economically attractive method of reinforcement consists in forming in columns of several meters of aggregate with different granulation, in a grid of regular spacing. Due to the specificity of the method, it is important to check the design assumptions, i.e. the length, diameter and stiffness of the columns. This is done on the so-called test specimens, done before commencing the proper work. The lengths and diameters of the columns are checked by making holes. Penetration tests (static, dilatometric, dynamic) and/or load tests allow you to determine the rigidity of the gain. The latter consists in determining the "load-settling" relationship, most often in primary and secondary pressures, and in defining deformation modules. For this purpose, a rigid plate is placed on the column head and the load is carried out by ballast actuators. The size of the loading slab depends on the diameter and length of the columns and the predicted pressure under the slab. Often the diameter of the loading slab is smaller than the diameter of the column. The article attempts to determine the impact of the slab diameter used in the trial loads on the results of the "load-settling" and the deformation modules obtained on this basis. Calculations were made using the finite element method, 
calibrated on the basis of column load, spatial numerical model. For calculations, the models were: elastic-perfectly plastic and elastic-plastic with isotropic reinforcement.

\section{Dynamic exchange}

The dynamic exchange method colloquially referred to as rock columns, is a component of geoengineering, subsoil, partial land replacement [2]. In this method, the substrate is strengthened by hammering the aggregate by means of compacting the hammer (on average several times per column), with a high mass (from 10 to $25 \mathrm{t}$ ), from a height of up to $25 \mathrm{~m}$ [8]. Such reinforcements are made on land [3], [4], [6] and successfully underwater [4], [5], [11]. Before commencing reinforcement work, a working platform is prepared, after which a heavy crane can safely move (up to several tens of tons). The formation process begins with the crushing of the crater and the first crushed aggregate and the discharging of the crusher - figs. 1a and $\mathbf{b}$ [7]. At this stage, the rammer is thrown from a small height (up to several meters). As the reinforcement of the reinforced substrate increases, the height of the dump is increased to reach the hardware capacity (usually $15-25 \mathrm{~m}$ ). In the final stage of column formation (Figure 1c), the head is compacted again with less energy.

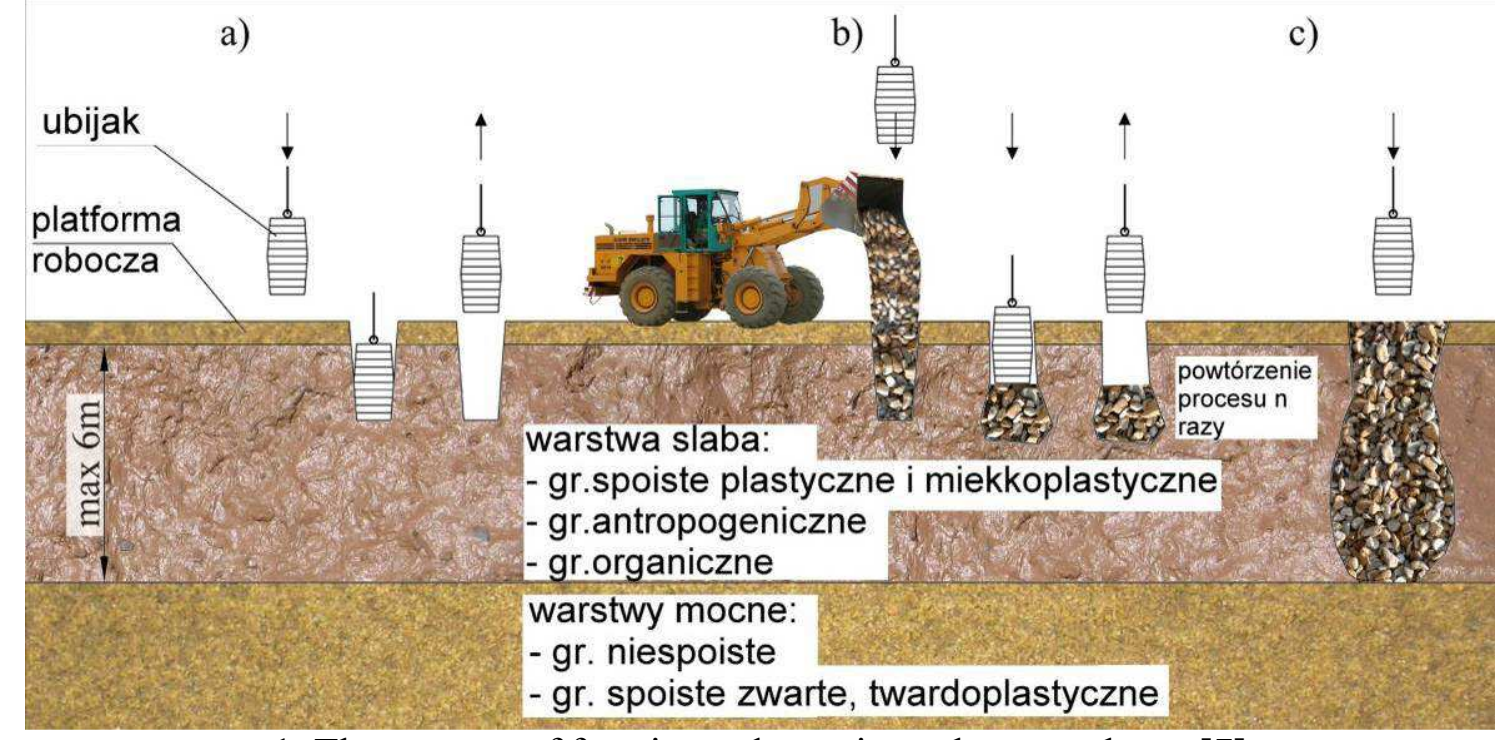

1. The process of forming a dynamic exchange column [7]

\section{Numerical model of substrate reinforced with dynamic change - the base model calibration}

The basis for the calibration of the model was the test of a load of a stone column carried out on the construction of one of the express roads in southern Poland. The presence of plastic organic soils with a thickness of over $10 \mathrm{~m}$ was observed. 2-3 m (Fig. 2), covered with medium thickened gravel and soft rock. 


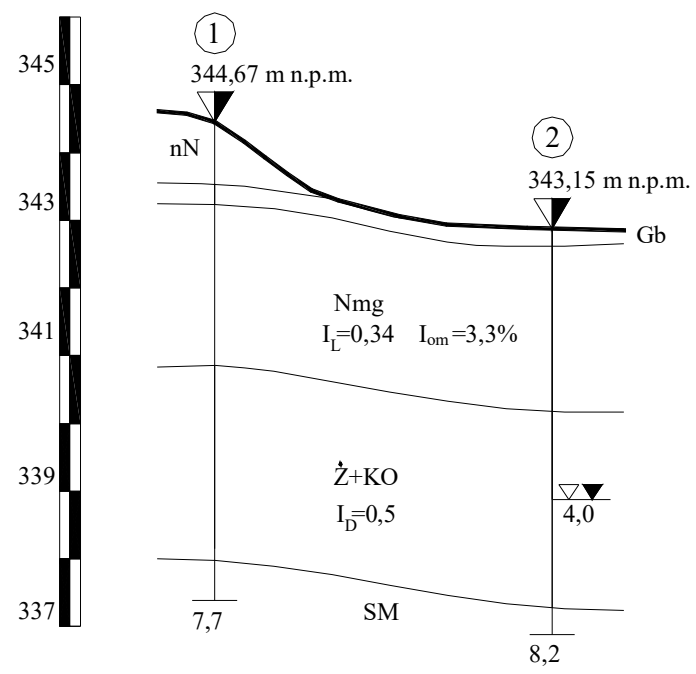

2. Soil and water conditions in the vicinity of the examined rock column

The substrate was reinforced with columns made in an equilateral triangle with a side of $3 \mathrm{~m}$, with a rock crusher of $0-400 \mathrm{~mm}$. The column was made up of $11.5 \mathrm{t}$ rammed, sliced 16 times from $13.5 \mathrm{~m}$ in height, in a plastic loamy bucket with a thickness of about $2.7 \mathrm{~m}$ (Fig. 2).Prepared for the test, the test stand is shown in Fig. 3.The retaining bar was a group of ten I500 I-beams, anchored in the ground by piles of 75 and $150 \mathrm{~cm}$ in diameter and 15.8 and $10 \mathrm{~m}$ in length. The larger diameter pile was one of the piles on which the bridgehead was based. The test load was carried out by means of constant load steps. Each stage was maintained until the settling speed of the column was at most $0.05 \mathrm{~mm} / 15$ minutes. The loads were made using three hydraulic cylinders with a range of $0-1300 \mathrm{kN}$ set on a $1.2 \mathrm{~m}$ diameter slab. The measurement made possible three electronic sensors with a range of $0-100$ $\mathrm{mm}$ and a reading accuracy of $0.01 \mathrm{~mm}$. The final end pressure was $\mathrm{q}=1373 \mathrm{kPa}(1553 \mathrm{kN})$, which was equal to about 1.5 times the theoretical load capacity of the Brauns column [1].

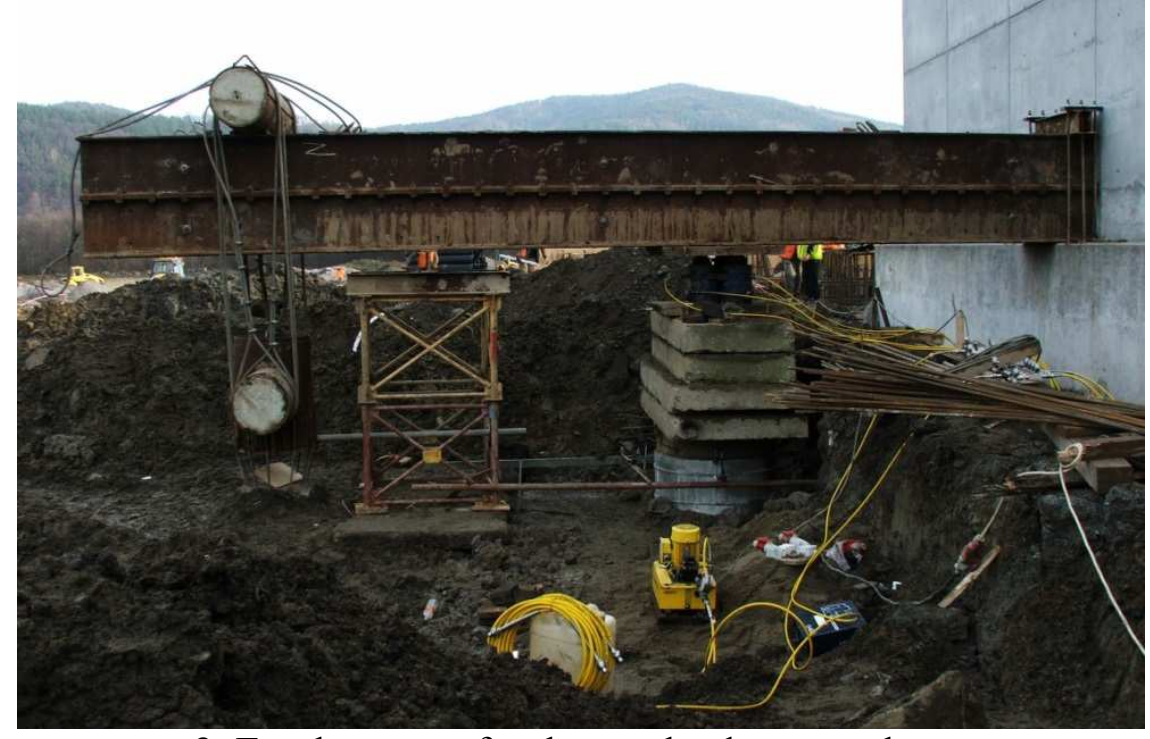

3. Emplacement for the test load stone column

\section{Selection of constitutive models of soil}

Considering the problem of reinforcement of cohesive (organic) soil with the granular material (stone column aggregate), it suggests the application of computational analysis of certain constitutive models of soil. In the case of granular soil forming the column as well as 
the layer of underlying soil, characterized by low compressibility, a flexible, perfectly plastic model with a Coulomb-Mohra boundary surface and a non-associated almost flowable form can be successfully applied. There are five solid materials in this model: modulus of elasticity - E, Poisson's ratio - $v$, angle of internal friction $-\phi$, cohesion $-\mathrm{c}$ and the angle of dilatation $\psi$.

The weak, strongly-deformable column environment, qualified for reinforcement, is generally poorly pre-consolidated. Large plastic deformations will prevail in large areas. The specificity of the driven columns approaches these models, whose reinforcement and plastic weakening are associated with changes in porosity, i.e., compacting and loosening the soil. Compaction of the surrounding environment is much more intense than in other technologies, thanks to strong dynamic consolidation (high hydraulic gradient formation in the soft environment in the vicinity of the columns as a result of dynamic high energy dissipation after the beaters impact the water from the pores of the fine particle to the columns). The density of the molding can be covered by the zoning heterogeneity. Further thickening and strengthening of the loading structure, however, requires a model capable of simulating these phenomena. This prefers models of critical state and, in particular, well known and implemented into FEM Modified Cam-Clay (MCC) programs. There are five solid materials in this model: slope of critical condition line - M, slope of the normal consolidation line (NCL) - $\lambda$, slope of the detente line $-\kappa$, parameter $-\Gamma$ associated with a critical porosity index and Poisson's ratio $-\nu$. For the concrete slab loading the column, a linear spring model was used.

\section{The essence of calibration and verification}

The criterion of the adequacy of a computational model is the accuracy of the fit of its loadsettling characteristic to the test load. Calibration of the computational model is a selection of ten parameters of constitutive constituent models of the column material and weak substrate, providing the best fit. The optimization process is realized by semi-back analysis. Some parameters were marked in the lab and treated as data. In view of the complexity of constitutive models, the best way to find the optimal set of parameters is by direct search techniques, with a number of MES analyzes simulating the trial load process. Verification of the computational model is reduced to the visual and statistical evaluation of the divergence of experimental data and theoretical predictions, with optimal parameter selection.

\section{Discrete model}

The model assumes the spatial layout taking into account the adjacent columns and the symmetry of the system. The shape of the columns was based on their outcrops. They were varied along the length of the "barrel" shape. The upper and lower diameters were 2,2 $\mathrm{m}$ and the center diameter was $2.7 \mathrm{~m}$. The length of the columns was $2.7 \mathrm{~m}$. The columns were supported by a layer of pebble with the addition of pebbles in a medium thickened state. The discrete model is shown in Figure 4. 


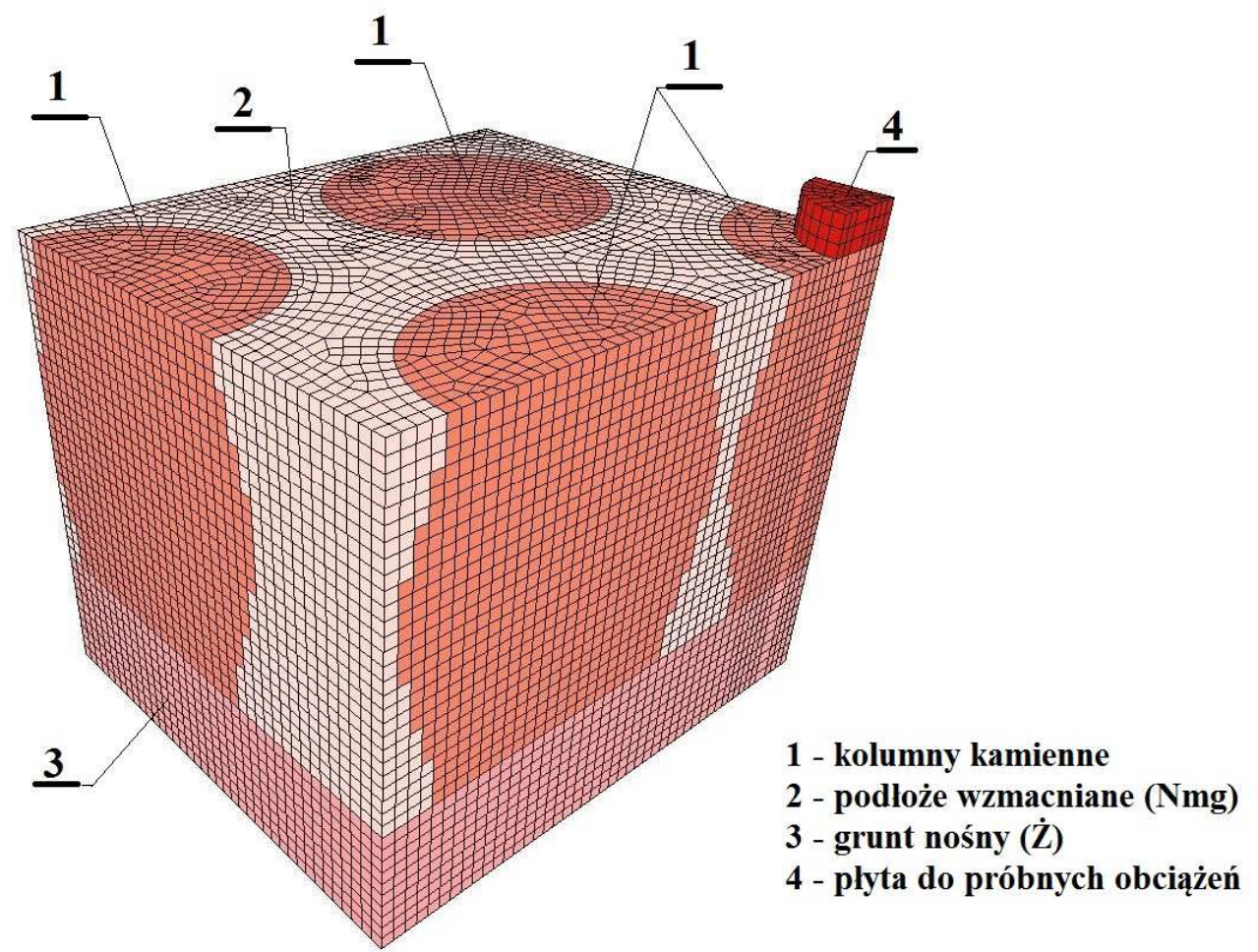

4. Discrete model of dynamic reinforced substrate

\section{Selection of model parameters}

The search for the parameters of the adopted land models was twofold. The parameters of the MCC model mapping were determined by laboratory tests on samples taken after the test load. These were triaxial compression tests and edometric tests.

Edometric studies, allowing to determine $\lambda$ i $\kappa$, were performed in the following cycles: primary stress $(0-200 \mathrm{kPa})$, detente $(200-12.5 \mathrm{kPa})$ and secondary stress $(12.5-400 \mathrm{kPa})$. Triaxial determination $\mathrm{M}$, was carried out with consolidation and drainage, on three samples pretreated with three isotropically applied consolidation pressures: 40,140 and $240 \mathrm{kPa}$.

The Poisson's ratio $v$ was adopted at 0.3 . It is located in the area administered by Lechowicz and Szymański [9], for organic land, the range: $v=0.23=0.45$.

The ground parameters of the model were adopted on the basis of geotechnical documentation. The parameters of the linear-elastic model simulating the work of the concrete slab were based on the norm PN-B-03264 as for the concrete B15 (C12 / 15). The size of the rock crusher fraction $(0-400 \mathrm{~mm})$ used to form the columns prevented laboratory tests in direct shear and edometry and field machines (except for the test load). Hence, it was decided that some of the parameters $(\phi, c, \psi)$ mapping the material of the Coulomb-Mohra model would be estimated by means of semi-analytical method conducted by the heraldic method. Modulus of elasticity was assumed by Pieczyrak [10] as the tangent of the initial slope of the experimental "load-settling" curve, and the Poisson's ratio behind the Jurik.

After the numerical analysis, the desired parameters of the column were determined, for which the numerical curve best reflects the field test curve (Figure 5). The modified coefficient of determination was $\mathrm{R}^{2}=0.994$. The list of selected constitutive models and their parameters is presented in Table 1 . 


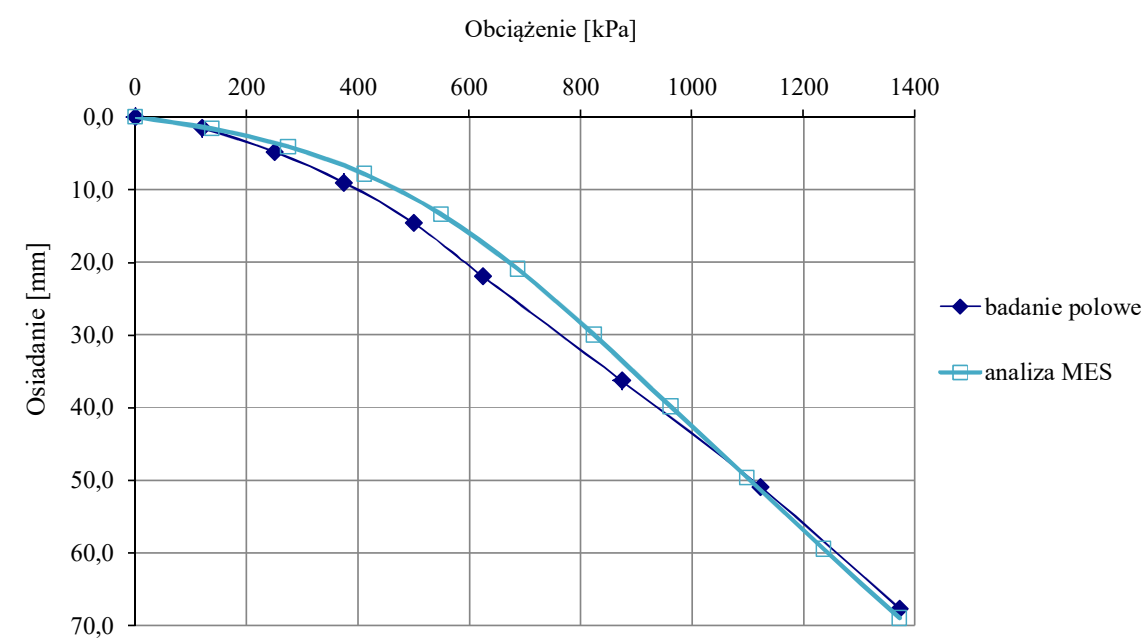

5. Results of FEM analysis

Tab.1. A summary of parameters of constitutive models accepted and obtained in FEM analysis.

\begin{tabular}{|l|l|l|}
\hline & Constitutive model & \multicolumn{1}{|c|}{ Parameters and initial values } \\
\hline Concrete slab & Liniowo sprężysty & $\mathrm{E}=27 \mathrm{GPa}, v=0,2$. \\
\hline Stone column & Coulomb-Mohr $(\mathrm{M}-\mathrm{W})$ & $\mathrm{E}=76 \mathrm{MPa}, v=0,2, \phi=46^{\circ}, \mathrm{c}=5 \mathrm{kPa}, \psi^{\circ}=20^{\circ}$ \\
\hline Silt & Modified Cam Clay & $\begin{array}{l}\lambda=0,053, \quad \kappa=0,0028, \quad \mathrm{e}_{\mathrm{o}}=0,84, \quad \mathrm{M}=1,48, \\
\mathrm{OCR}=1.1, v=0,3 .\end{array}$ \\
\hline Gravel + pebbles & Coulomb-Mohr $(\mathrm{M}-\mathrm{W})$ & $\mathrm{E}=140 \mathrm{MPa}, v=0,25, \phi=38,5^{\circ}, \mathrm{c}=0 \mathrm{kPa}$ \\
\hline
\end{tabular}

\section{Computational analysis of the impact of the loading slab diameter on the test results}

The calibrated dynamic substrate model was used to investigate the effect of the loading plate diameter on the test load. In the analysis, the load of the plates was: $0.3 ; 0.6 ; 0.9 ; 1.5 ; 1.8$ and $2.2 \mathrm{~m}$. The ratio of the loading plate diameter to the diameter of the column head $-\left(\mathrm{D}_{\mathrm{p}} / \mathrm{D}_{\mathrm{g}}\right)$ amounted accordingly: 0,$14 ; 0,27 ; 0,41 ; 0,55 ; 0,68 ; 0,82$ and 1 .

The results of calculations in the form of the "load-settling" relationship are shown in Figure 6.

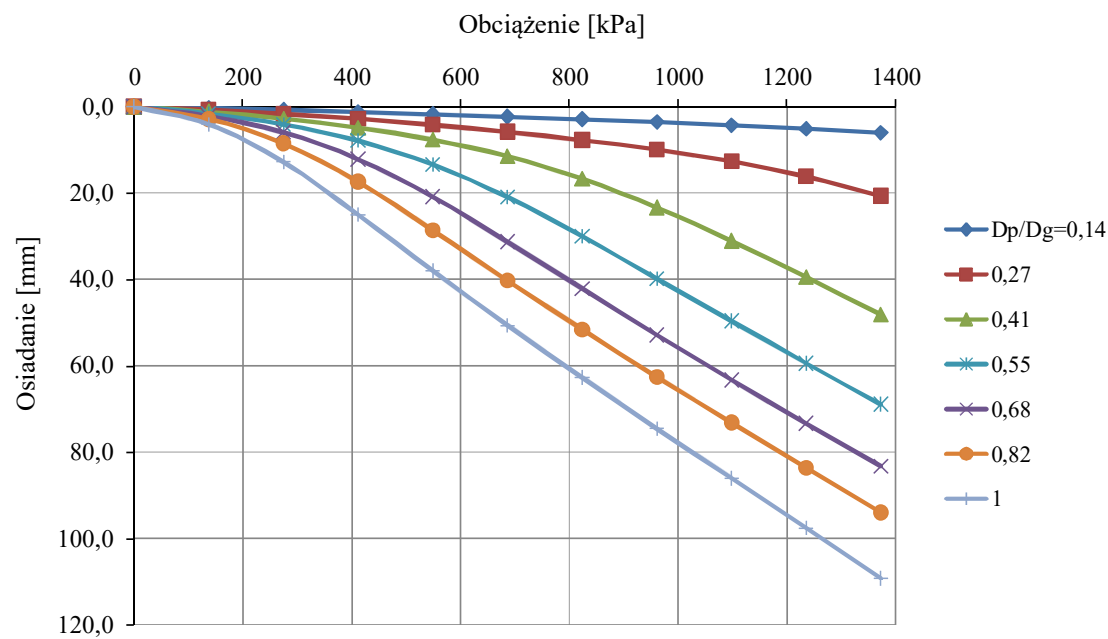

6. The "load-settling" relationship when used in trial loads of different diameter slabs 
It can be seen that the larger the diameter of the disk loading, the higher settling. In the case of a slab with a diameter of $0.3 \mathrm{~m}$, the final settlement was about $6 \mathrm{~mm}$, while for a diameter of $2.2 \mathrm{~m}$ it was approximately $110 \mathrm{~mm}$. This dependence occurs even on a uniformly homogeneous substrate characterized by constant stiffness. The larger size of the loading plate engages the greater area of the substrate, resulting in greater settling of the system. In the case of a column reinforced substrate, in addition to the horizontal stratification (reinforced soil, supporting soil) we have a vertical stratification (column, ground environment, adjacent columns). This affects the response of the system in the form of displacement. Figure 7 shows the extent of occurrence of accidental displacements with increasing loading plate diameter. It can be seen that the response of the tested system in addition to the stiffness of the loaded column and the ground environment also affects the spacing of the columns and the thickness of the reinforced substrate. In the case in question, the adjacent columns limited the displacement caused by the load already for the slabs of diameter $\mathrm{D}=0,6 \mathrm{~m}$ and bigger $\left(D_{p} / D_{g} \geq 0,27\right)$. The effect of the carrier layer was revealed for slabs with a diameter above 1,2 m.

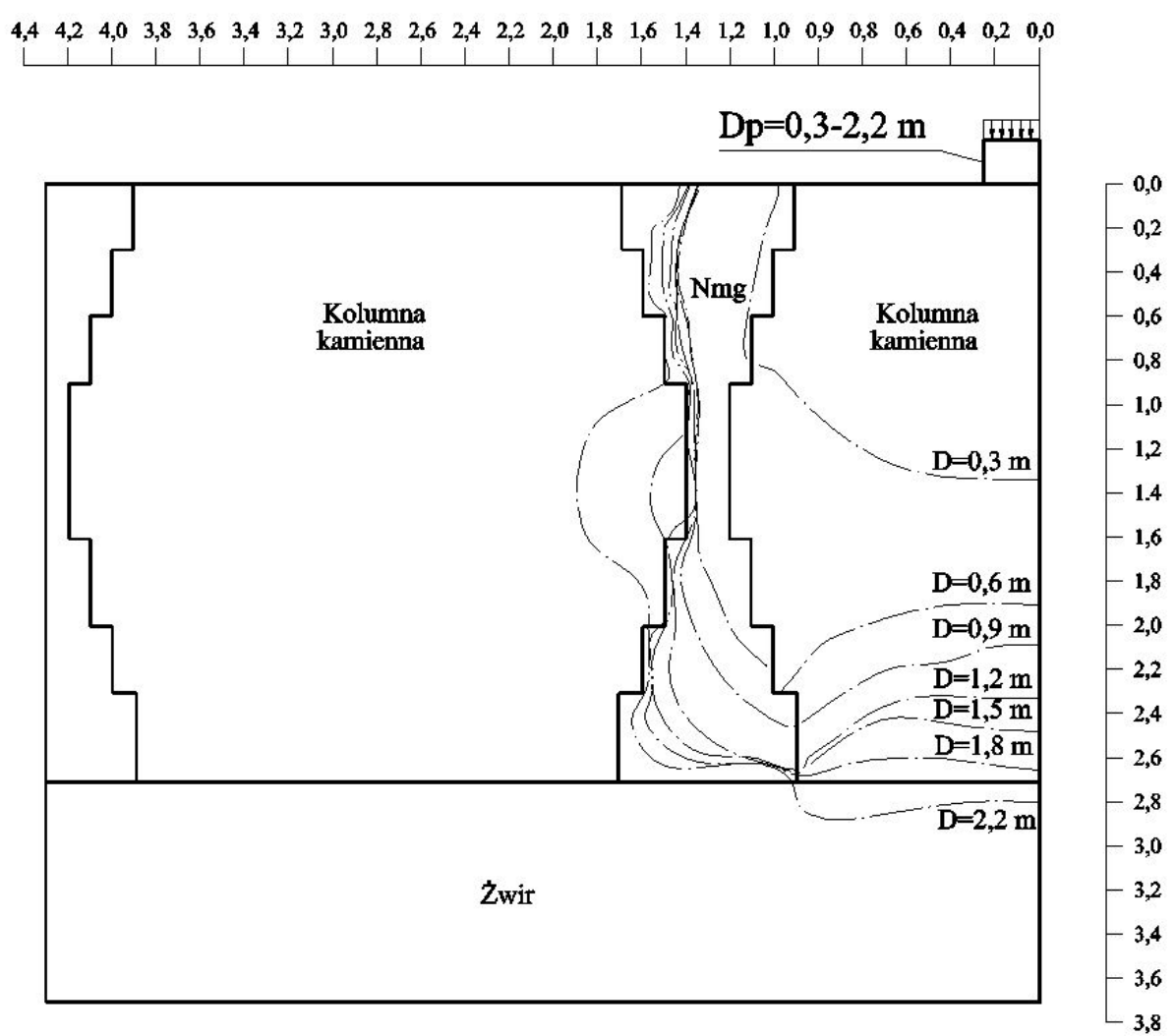

7. Isolines zero accidental displacement in the axial section of the columns

In the case of trial loads carried out in field tests, the load-settling curve is the basis for determining the deformation modulus of the substrate. The three-dimensional deformation method is used here as part of the theory of elasticity. To show the influence of the loading slab diameter on the stiffness of the examined system, the deformation modules were calculated based on the results of the graph $\mathbf{6}$. The results are shown in Figure 8. According to previous considerations, the substrate was tested with a $0.3 \mathrm{~m}$ diameter slab - the deformation modules were equal to 50-90 $\mathrm{MPa}$, while the smallest ones were respectively using a plate with a diameter of $2.2 \mathrm{~m}$ - deformation modules from 20-55 MPa. The elastic modulus of the columns determined by semi-conductivity analysis was $76 \mathrm{MPa}$. 


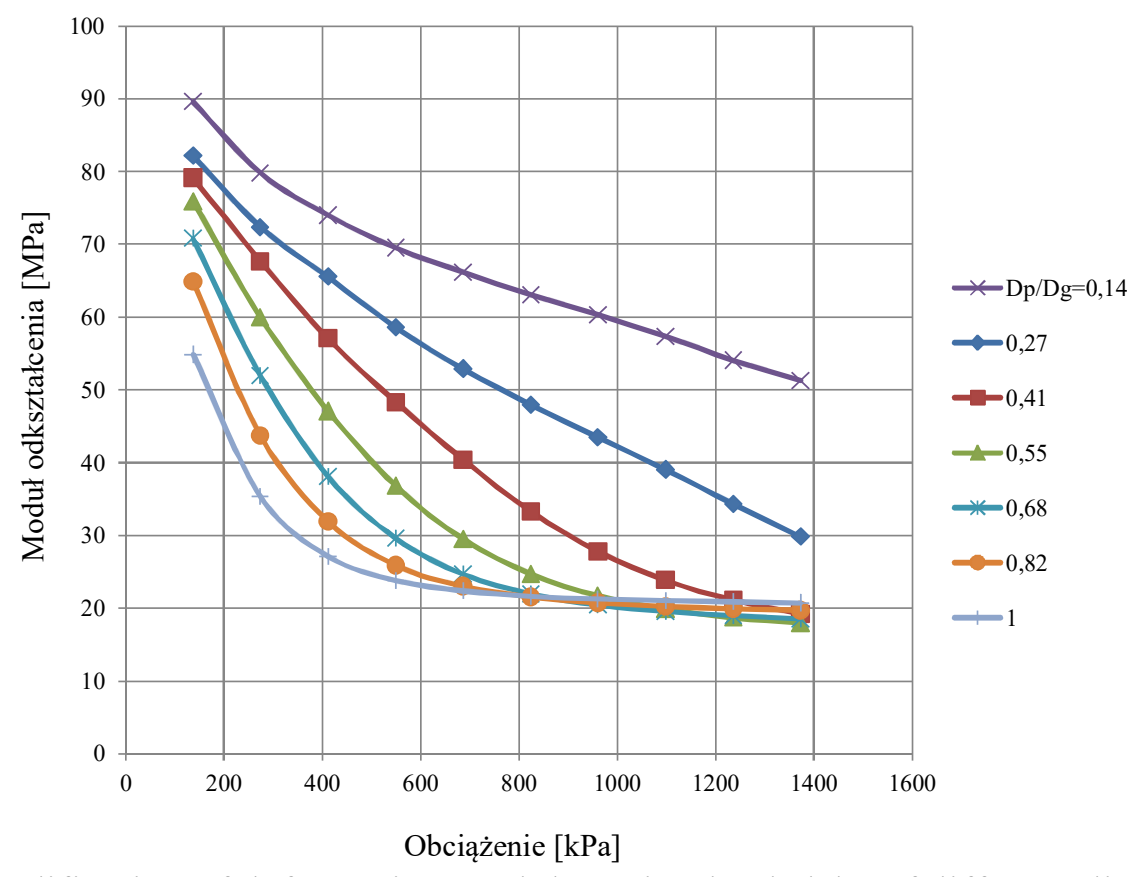

8. Modification of deformation modules using load slabs of different diameters

\section{Conclusions}

The calculations have shown that the diameter of the slab used in the test loads affects the response, the substrate reinforced with the dynamic exchange, expressed as a "load-settling" curve and the deformation modules obtained on the basis thereof. The use of small diameter slabs $\left(D_{\mathrm{p}} / \mathrm{D}_{\mathrm{g}} \leq 0,14\right)$ in the tests only pulls into the column, so the system's response is determined by the strength and deformation parameters of its own. The use of slabs with small diameters eg $0.3 \mathrm{~m}$ (VSS) is, however, problematic. Firstly, it could only be used in the case of columns made of gravel, sand, sand. Second, they have a small depth range (about 4 $\mathrm{D}_{\mathrm{p}}=1,2 \mathrm{~m}$-Fig. 6). Then, for example, dynamic probes would be needed to test the lower part of the columns.

In the case of the use of larger diameter slabs $\left(D_{p} / D_{g}>0,14\right)$ in the test load, the surrounding of the column, in the form of reinforced soil and even adjacent columns, is affected. The latter in the analyzed case has already appeared for plates with a $D_{p} / D_{g} \geq 0,27$. For this group of tests $\left(D_{p} / D_{g}>0,14\right)$, based on their results, column parameters (eg C-M model) require modeling of the test load as in this article (spatial analysis). This allows the designer to check the construction parameters of the columns at the design stage.

\section{Source materials}

[1] Brauns J. Initial bearing capacity of stone column and sand piles. Soil Reinforcing and Stabilizing Techniques in Engineering Practise. 1978, 477-496.

[2] Gryczmański M. Współczesne kierunki rozwoju geotechniki w Polsce. Inżynieria i Budownictwo, 1994, 339-347.

[3] Gwizdała K., Blockus M. Wzmocnienie podłoża gruntowego metodą dynamicznej wymiany (DR) dla posadowienia obiektów terminalu kontenerowego. Konferencja Naukowa z okazji Jubileuszu 70-lecia urodzin Profesora Macieja Gryczmańskiego. 14.6.2007, 167-176.

[4] Hamidi B. Distinguished ground improvement projects by dynamic compaction or dynamic replacement. Phd Thesis. Curtin University, 2014. 
[5] Hamidi B., Nikraz H., Yee K., Varaksin S., Wong L. T. Ground Improvement in Deep. Waters Using Dynamic Replacement. 20th International Offshore and Polar Engineering Conference. 20-25.06.2010, 848-853.

[6] Horodecki G. Ocena wzmocnienia podłoża metodą wymiany dynamicznej na podstawie próbnych obciążeń kolumn. Budownictwo i Inżynieria Środowiska, 2013, 4, 257-263.

[7] Kanty P., Kwiecień S., Sękowski J. Wpływ formowania wbijanej kolumny kamiennej na otoczenie gruntowe. Wydawnictwo Politechniki Śląskiej, 2015.

[8] Kwiecień S., Sękowski J. Kolumny kamienne formowane w technologii wymiany dynamicznej. Wydawnictwo Politechniki Śląskiej, 2012.

[9] Lechowicz Z., Szymański A. Odkształcenia i stateczność nasypów na gruntach organicznych. Wydawnictwo SGGW, 2002.

[10] Pieczyrak J. Ustalanie parametrów wybranych modeli gruntu na podstawie próbnych obciążeń. Praca habilitacyjna. Politechnika Śląska. Gliwice, 2001.

[11] Varaksin S., Hamidi B. Ground improvement case histories and advances in practice. International Conference on Ground Improvement and Ground Control. 30.1002.11.2012, 209-222.

[12] Wiłun Z. Zarys Geotechniki. Wydawnictwo Komunikacji i Łączności, 2003. 